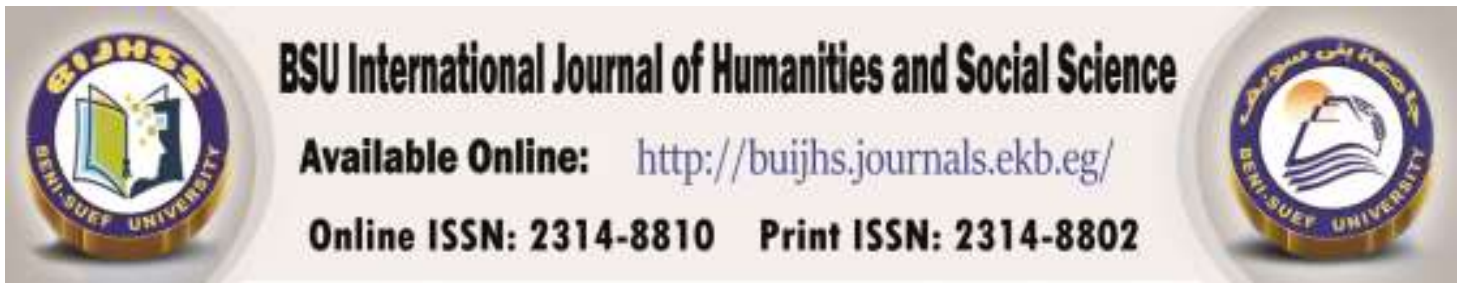

\title{
Manifestations of Racial Discrimination as Shown in selected Poems by Maya Angelou Hanaa Khalifa Mohamed Eid*
} Under the supervision of Prof.Mohamed Mohamed Enani † Dr. Shaymaa Sayed Abdel Aatty ${ }^{\ddagger}$

ABSTRACT

\section{ARTICLE INFO}

Received 2020-04-18

Accepted 2020-05-11

\section{Keywords}

Maya Angelou

African American

Racism

Racial Discrimination

Black feminism
This research aims to highlight the unique existence of black women as they go on their daily lives in a land in which tyranny over women is still evident. Maya Angelou is a poet who presents the existence of being black, poor, and female. She speaks in a voice for oppressed African-American women and men as she says, that she: "writes for anyone in a cage". Her political works are characterized by a spirit of survival and success, and she presents it with such eloquent singing. A close reading of Angelou's poetry reveals themes grounded in racism, sexism, and class distinction. This study aims at reading the poetry of Angelou as a resistance to the racist and sexist prejudices that affected the African community.

\footnotetext{
* Teaching Assistant in English Literature, Beni-Suef University , Egypt

${ }^{\dagger}$ Professor of English Literature, Cairo University, Egypt

${ }^{\ddagger}$ Lecturer in English Literature, Beni-Suef University, Egypt
} 
Maya Angelou is considered one of the prominent African American poets in the last century. Black people; called the African American slaves had suffered a lot during the civil war; thus, Angelou defends them and herself in the poetry she wrote. She chose to write in the form of autobiography in order to reflect her own experiences as an African American woman. As a feminist, she has done great job defending the rights of all black women. She has gained many rewards as an influential writer who affected literature and activism. (Krisna \& Soelistyo 94). She was born in 1928. Her name was Marguerite Ann Johnson. She was born in St. Louis, Missouri. Her parents were divorced when she was too little. Her brother Bailey was a year older than her. Because he could not pronounce her name he said "Mya sister" instead of Maya The nick name was later shortened to Maya. Her name was then changed to Maya Angelou. (Kirkpatrick 2). Bailey and the little girl went to live with their grandmother for three years. Then, they returned back to spend the time with their mother to take care of them.

Angelou established her literary reputation in the $1970^{\text {ee }} \mathrm{s}$ despite her desperate early years, and she progressively succeeded to be one of the prominent writers of the century (Malika 29). She wrote prose, poetry, screen plays, songs, short stories, and more. "In the 1950s also, she was "involved in the civil rights movement. In this period, Angelou and her son spent a number of years living in Cairo, Egypt and Ghana." All of the autobiographical works have been produced as adult looking through the eyes of the child and young woman who portrays the experience of a black, female individual who has had to find an Identity through the experiences she lived. (Naderi 4-5). Naderi claimed that Angelou was the first African American to be given the honor to write and read the poem for the inauguration of President Bill Clinton. She wrote "on the Pulse of Morning" 1993 at the inauguration ceremony. She has received a lot of national and academic honors. She was granted the presidential Medal of the Arts in 2000, she was also conceded her first privileged doctorate degree in 1975 and finally in 2011, she was awarded the presidential Medal of freedom; the America's highest civilian honor, by President Barak Obama. (5) 
Come, rest here by my side.

The Rock cries out to us today,

You may stand upon me,

But do not hide your face.

Across the wall of the world,

On the Pulse of Morning

When Angelou was sent back to live with her mother, she was raped by her mother's boyfriend. When she was asked about the rape accident in an interview, she declares:

I was taken from my grandmother in Arkansas at seven to St Louis, and I stayed there with my mother's people, and after a few months her boyfriend raped me. He was put in jail for one day and released, and a few days later the police came and told my maternal grandmother that he had been killed, and it seemed he had been kicked to death. At that moment I thought that my voice had killed him, so it was wise not to say anything at all, just in case my voice would go out and kill people. And so I stopped speaking. (On line)

When Angelou began to write she was too old. She was forty one when her first autobiography was published. Her six autobiographies are considered her masterpieces through which crucial events are covered in American history such as the segregation in the South, the Second World War and the Movement of Civil Rights. Her first autobiography I Know Why the Caged Bird Sings (1970) shows portrait of her early life in the South; during the thirties and forties, "Gather Together in My Name" reflects 
her life as a young woman. She struggles to provide a secure life for herself and her son. Singing' and Swinging (1976) illustrates her young adult life in the 1950s. The Heart of a Woman (1980) narrates the roles of a wiser more mature mother in the 1960s. And All God's Children (1986) examines her late experience in West Africa. Besides her five volumes of autobiography, Angelou wrote six collections of poetry which represent her experience in the world of African Americans. Her poetry also reflect her quest for selfidentity. She also has a presidential inaugural poem.

Being African American, Angelou's poetry reflects her identity, race, gender and culture. Maya Angelou has awarded many doctoral degrees although she did not attend college. She depicts her own experience, such as her "early trauma, young pregnancy and child birth, single motherhood, and continuous attempts to juggle work and child care" (Wedin 57). Malika asserts that as a black female, Angelou had faced several disappointments and dissatisfactions during her life, but she never gave up, instead, she hold on and defeat her failures. (30)

In her poetry, Angelou tackles themes such as marginalization, oppression, discrimination and stereotyping. She also focuses on women's situations; she addresses the eternal struggles that African Americans suffered in a segregated society. Her messages concerning human dignity and social equality make her one of the most phenomenal women. (Maria Rosan 8). Wongpinit assures that Angelou suffered from inferiority and humiliation when she was young as a result of racism. When she grows up, she still suffers as a black female. She recalls the past, and understands her situation in the present, and she bears in mind that she is responsible to defend not only her own rights, but also the rights of her people (123). Mumena Ghani states that: thematically, Angelou reveals mental, psychological and social aspects of Afro American culture. Angelou's works deal with topics of adoration, of affection, dismissal, acknowledgment, racial contrasts. Angelou's literature investigates numerous points such as sociopsychological inferiority, desire for liberation and socio-mental mediocrity, want for freedom and outrage against underestimation shapes. She 
additionally researches the impact of the white's way of life on black values and esteems. (24)

To underscore the importance of black women, Angelou argues that as black women were wage earners, they were equal with their men. They faced patriarchy like white women, however, black men did not consider them unnecessary in the public sphere such as white women who were told by their men that they were not needed. Hence, recently, black women are no more fighting for the right to work. It can be concluded that women's movement is oriented towards white women, while womanists restrict themselves to gender concerns. (Z.Koyana 7-9). Angelou emphasizes the difference between black and white women's roles in the period before the women's movement. Angelou comments that black women have helped their husbands by working inside and outside the home. As a result, for Angelou black women are not totally powerless like their counterparts. For Angelou, the challenge of racial and class exploitation is a primary concern.

As an African American author, Angelou reflects her own identity through depicting her culture, race and gender. Doing so, Angelou follows the black feminist movement whose aim is to liberate. As Wedin claimed, Angelou uses the word "Womanist" instead of "feminist" (64). Black feminists aim at ending the political and economic oppression of black women. While feminism is fighting for gender equality and sexism, black feminism is fighting for both sexism and racism; black feminism in general is concerned with black women's identity. Women have passed through various issues and problems; previously, they have no rights, they were ignored, abused neglected and rejected by men. Feminism makes them significant members in society as it totally changes the women's image. Now women have important roles in society instead of being a puppet in the hands of men. Feminists have focused on the issues of the women of the middle class; they neglected the colored women of the lower class. While feminists resist against the male domination and fight, "Angelou espouses a version of feminism called Womanism. This is an afro-centric feminist practice encouraging co-operation with men in the struggle against racial and 
economic exploitation. As a theory, Womanism is applicable both in the African context, where communities are slowly recovering from the destruction caused by colonialism and imperialism and in the African American context with its history of slavery and continuing racial oppression. "(Siphokazi Z.Koyana 4)

Angelou has been married several times but none of them survived. She does not like to be bound with man in a relationship. "Angelou's notion of oppression of woman produces the image which leads to truncated life based on her pride on gender and her individual being with reference to poverty, illiteracy, silence and traditional boundaries" (Ghani 10). Angelou disagrees with the nature that supposes man should be in charge. With frustration she says " I wanted to be a wife and to create a beautiful home to make my man happy, but there was more to live than being a diligent maid with a permanent pussy" (Angelou 143)

"Since you're black, you have to hope for the best, be prepared for the worst, and always know that anything happen"

Her poetry is also an effort to show how the black women are seeking to survive against masculinity in addition to whites' hatred of blacks. (Ghani 1) African American female authors illustrate in their works the result of social, psychological and economic experiences. For Maya Angelou, she struggles for her own identity, which reveals how she sacrifices herself for her family, community and race. Maya Angelou illustrates in her essay "They Came to Stay" that black women in the United States have lived through cruel and horrible conditions. (Wongpinit 11-13) Naderi states that Angelou's creative writing and poetry especially that outstanding autobiographies which brought her international recognition. Much of Angelou's poetry expresses themes common to the life experiences of many African American women. All images of black women in her poetry share some common features. (2) 
Maya lost security and sense of belonging when she was separated from her father and mother. She was only three, but she never forget this displacement moreover, she never regain the sense of security. "Her displacement from her family is not only an emotional handicap but is compounded by an equally unsettling sense of racial and geographic displacement". Racial prejudice in Stamps limit the lives of Angelou and her brother; they were alienated: "If growing up is painful for the Southern Black girl, being aware of her displacement is the rust on the razor that threatens the throat." It was difficult for a little black girl to endure all this pain. (2)

"I saw only her power and strength. She was taller than any woman in my personal world, and her hands were so large they could span my head from ear to ear."

"I would always wear pretty aprons and my son would play in the Little League. My husband would come home (he looked like Curly) and smoke his pipe in the den as I made cookies for the Scouts meeting," or "We would live quietly in a pretty little house and I'd have another child, a girl, and the two children (whom he'd love equally) would climb over his knees and I would make three layer caramel cakes in my electric kitchen until they went off to college." "With my courage added to his own, he would succeed in bringing the ignominious white rule in South Africa to an end. If I didn't already have the qualities he needed, then I would just develop them. Infatuation made me believe in my ability to create myself into my lover's desire." It was a miracle that after all what Maya Angelou endured, she survived, struggled, graduated from college, found the job she dreamt of, and continued on her way toward success.

According to Sarah Gamble, feminism seeks gender equality. Although feminist concerns may cover both genders, women have the large part of its discourse. (47) Rosan argued that two adjectival derivations emerged from the words men and women; which are: feminine and masculine, and female and male. Feminine and masculine are used to refer to social and cultural 
constructions while the adjectives female and male represent biological constructions. (9)

\section{Rosan suggests that:}

As we towards a society that is increasingly diverse regarding religious affiliations, sexual orientations, and ethnic backgrounds, it is necessary to recognize and accept differences among people, the intersectional feminist theory calls into attention this particular issue of acceptance that has been a problem for a long time even inside feminist movements. To understand intersectional feminist's claims, a short history of race and gender representation that highlights the main stages of the black intellectual theory is necessary, for more understanding to the links and differences between black intellectuals' claims (9).

The difference between human beings brings the issue of race from which emerges the term Racism. As Sunday noted, "Racism means that a group's physical characteristics determine their superiority" (44). African Americans experienced racial discrimination in the United States. The lower class feel inferior to the superior upper-class; from which class distinction has emerged. Gender discrimination means that men are better than women, children learn this early as Eckert et al note:

From the time they are very young, most kids have learned to desire that perfectly matched partner of the other sex. Girls develop a desire to look up at a boyfriend. A girl begins to see herself leaning against his shoulder, him having to lean down to kiss her, or to whisper in her ear. She learns to be scared so she can have him protect her, she learns to cry so he can dry her tears. Girls put on large men's shirts to emphasize their smallness. Learning to be male or female involves learning to look and act in particular ways, learning to participate in particular ways in 
relationships and communities, and learning to see the world from a particular perspective. (17-18)

Eckert et al mean that, on the level of labor, gender attributes domestic work for women; as they bear children and nurture them. On the other hand, it attributes the public realm to men; as they are responsible to control the means of production. On the level of sexual division, gender attributes jobs that are extensions to domestic work to women that involve service roles; such as teachers and nurses (24-25).

E.Phields assume that racism and sexism also participate in shaping gender roles ideology and personality traits of women, especially, black women. Racial oppression denied African American Women the ability to conform to societal standards. Racist and sexiest forces shaped black women's culture from the traditional norms and they had to change their roles from traditional norm to survive the harsh societal and environmental forces; their roles evolved from a history of oppression and slavery. African American women deviated from the traditional gender roles to ensure the survival of their families, thus, they acquire characteristics of both masculinity and femininity. (14-15)

African American women can survive and endure hard labor because they have physical strength. The strength is also found in their emotions as they are sacrificing. They are capable of assuming responsibilities for sustaining her family through harsh social and economic conditions, they are even stronger than black men. To survive, black women must remain strong and show love, regardless of what happens to her, or what she faces; they are proud of this strength. (E.Phields 21)

Angelou's works describe mothers and grandmothers and other notable women and a strong and tenacious they play strong role in gender socialization. Black women also acquire another masculine characteristic which is self-reliance. It is a non-traditional gender role trait for women. Black women are socialized to take care of their families and themselves without a man is not around. (E.Phields 24) 
African Americans are prisoned in Racism; they cannot get selfrealization. They are always represented as uncivilized, barbaric and inferiors. This study aimed at reading poetry of Angelou as a resistance to racist and sexist prejudice es affected the African American community.

In an interview, Angelou was asked about the importance of knowing oneself and she replied:

"We may encounter many defeats, but we must not be defeated. It may even be necessary to encounter the defeat, so that we can know who we are, so that we can see, oh, that happened, and I rose. I did not run away. I rose right when I'd been knocked down. And then that's how you get to know yourself" (Angelou)

Angelou is worried about the oppression on the African American women who are considered victims of sexism and racism. According to Guha" Racism is in discriminatory treatment of a sect of people by the other in the context of America, the black people are deemed to be inferior, uncivilized in comparison to the white people who are considered to be the epitome of civilization, superiority and beauty “(49).

In school days, she was not the ideal girl; boys annoyed her because of being ugly according to their view but now she is no more afraid of them. She said:

That new class room where

Boys all pull my hair

Kissy little girls

With their hair in curls

They don't frighten me at all

In this poem, she gathers all the things in her life that she has to overcome. Whatever she encountered in her life, she has not to be afraid. She reinforces this idea at the end of each stanza. "life doesn't frighten me at all". She also refers here to discrimination, crime, pain, prejudice, and all the negative emotions that she had to face. "I just smile, they go wild" smiling is a starting point to her to face all her fears. Fear to Angelou is like an enemy; 
she reminds herself all the time that she can fight and defeat whatever stops in front of her; fighting back, resistance, and protest are steps to defeat the fear.

The dehumanizing representations of women place them in domestic sphere. The poem "woman work" explores the roles the patriarchal order assigned to females because of their gender." I have got the children to tend" Angelou also addresses women's suffering and painful lives in her poetry. In her poems equality and remembrance she wrote:

Cause I laugh like I've got

Diggin in my own backyard

You may shoot me with your word

You may cut me with your eyes

You may kill me with your hatefulness

She depicts the bitterness of being treated unfairly; she reveals inferiority. Women are engaged in domestic work. They attend the children and husband. She is also forced to perform her duties as a sweeper, caretaker and a Gardner. Activities a female have to do involve her attending to others not to herself. Her life is not her own. In an interview with Angelou, she was asked about her mother and what she had learned from her, she answered:" she admits that writing poetry is one of the most challenging professions she has taken on" she says also "I've listened to an inner voice and had enough courage to try unknown things. Asking Angelou about courage she concludes that: I've seen evidence of kindness and generosity and those have been the turning points in my life which confirmed my belief in my printing to be kind and generous. Women are only treated as mothers, daughters, and wives. They can do housework. However, Angelou shows that women are not at the margins but they are strong and can work side by side with men. Colonization era has brought slavery which had a disastrous effect on African- American s especially women because women were physically and sexually harassed by their masters. 
Angelou focuses on themes of resistance and marginalization Resistance for Angelou is a process of cultural liberation. She draws an image of the racist domination and how this affects the marginalized people both through brutal racism and sexual abuse. In other words, black women struggle not only against masculine prejudice but also the hatred of whites.

Angelou resisted against racism to achieve the dream of her ancestors; they struggled and fought for freedom. Angelou, the black American woman, living in South; survived and succeed to reward her them. They lived in a society where only white beauty is praised; comparing herself to the white beauty, Angelou feels she is ugly and unattractive. Thus, she feels inferior.

Racism and discrimination is also found in the bad treatment of black Americans. They are humiliated and badly treated in all aspects of life. They were also isolated and segregated in schools and restaurants. The black Americans lived in Stamps Arkansas in 1930s and 1940s were humiliated under the social, economic and political white power. Maya Angelou stated: "In Stamps the segregation was so complete that most of Black children didn't really, absolutely know what whites looked like." (27)

She wrote "Since there was no Negro dentist in Stamps, nor doctor either, for that matter, Momma had dealt with previous toothaches by pulling them out." (36 Malika).

In a poem" life doesn't frighten me", she speaks about Racism. The speaker talks about oppression brought about by racism. Here, oppression touches both males and females

Shadows on a wall

Noises down the wall

Life doesn't frighten me at all

Bad dog barking loud....... 
The speaker wants to say that the oppression which frighten her is only dream. Despite all the obstacles she says that African Americans should come out of their fears of repression. Angelou is conscious about the "race" as faced by blackness. The essential difference lies in the shape, language, accent, color, skin. These are signs to be inferiors. Through her poetry, Angelou depicts the gaps between whites and blacks. (Ghani and Vaz 102). Angelou's poems also proves that black females are struggling to free themselves from patriarchal subjugation. As racism is a dominant theme in Angelou's poetry, the research proves that black women have struggled not only against racism of whites but also the racism of black males.

Throughout history, sexism and gender roles in society has been a greatly debated topic. The Women's Rights Movement and other movements worked against the appointment of gender roles and sexiest beliefs. It is noticeable that gender roles and Sexism are central themes in the works of Maya Angelou. The poem "men" Angelou positively portrays the image of women Angelou irls in sexual acts exposes the experiences of African American females. She shows how men engage under aged girls in sexual actions. "When I think about myself" is another poem dealing with Racism maya explores the humiliation she experienced when she works for children.

60 years in this folk world

The child I work for call me girl

I say yes ma'm

For walking sake

Too proud to ..

Too poor to break

Because of her race she is seen as inferior and doesn't deserve respect. African Americans are referred to as inferiors, barbaric and uncivilized Guha asserts that" the victimhood of the black woman is more serious as she is repressed on the dual grounds of her race and gender. . Angelou's poetry is a 
resistance to the racist and sexist prejudices and it calls for equality and justice.

Ria Risky claims that Angelou highlights the idea of Racism as she was an African-American activist. Racism deals with "slavery, discrimination, segregation hegemony prejudice and stereotypes and class struggle."(Risky 2015). Through diction, imagery, and choice of words, Angelou has highlighted the theme of Racism; the poem "Still I Rise" is one of the most inspiring poems in regard of Racism. In this poem, Angelou recalls the past of her ancestors who suffered from slavery and oppression. As a strong, powerful woman, she intends to leave the past behind and look forward to the future.

African Americans are prisoned in Racism; they cannot get selfrealization. They are always represented as uncivilized, barbaric and inferiors. This study aimed at reading poetry of Angelou as a resistance to racist and sexist prejudice es affected the African American community.

In an interview, Angelou was asked about the importance of knowing oneself and she replied:

"We may encounter many defeats, but we must not be defeated. It may even be necessary to encounter the defeat, so that we can know who we are, so that we can see, oh, that happened, and I rose. I did not run away. I rose right when I'd been knocked down. And then that's how you get to know yourself" (Angelou)

Angelou is worried about the oppression on the African American women who are considered victims of sexism and racism. According to Guha" Racism is in discriminatory treatment of a sect of people by the other in the context of America, the black people are deemed to be inferior, uncivilized in comparison to the white people who are considered to be the epitome of civilization, superiority and beauty "(49).

The research proves that Angelou asserts and recommends that black women can only attain their independence through work and education instead of childbearing and housework. Her poetry shows her sense of racist oppression that African American have been subjected to. She is also aware 
of sexist oppression that she realizes through her own experience. As she was a victim of sexual abuse when she was a child. She also worked as a prostitute for two years. Angelou's poetry exposes and resists both sexism and racism. She believes that gender inequity will not be achieved unless we get rid first of racial inequality. The researcher concludes that women are able to behave like men, simply, because women, although considered as powerless social group, they can have the same values and strategies of men.

The quest for identity formation has been a recurrent theme in African American writings. The African American writers in their works encourage black people to fight domination and assert themselves from subjugation. Angelou, in her poetry, deals with African-American males and females who are victims of racism, sexism and class oppression, whom she considered a result of colonization. . Angelou also reveals the bad conditions of black women who suffer from subjugation by both white and black men. Children implies the "physical limitations on Black women's mobility" (Collins 105) (Jana Drešerova 38)

On the other hand, Angelou has also experienced unfair and violent situations in her life. She could not ignore this harsh reality. Instead, she did not give up on hope. One of those experiences was the rape she survived at the age of eight; she became silent, thinking that uttering the name of her rapist would cause his murder. She found her voice again through poetry and literature. This is clearly evident in her poem: Leaving

Behind nights of terror and fear

I rise

Into a daybreak that's wondrously clear

I rise

(Still I Rise) 
Angelou is inspired by her ancestors' long history of resistance, this build up her strong personality. Her ancestors have dreamt to achieve freedom and she is proud to feel herself part of that freedom as she describes herself "the dream and the hope".

Bringing the gifts that my ancestors gave,

I am the dream and the hope of the slave.

I rise

I rise

(CCPS 164)

Throughout history, the whites maltreated and oppressed black people as shown by Angelou in the following lines:

Out of the huts of the history's shame

I rise

Up from a past that's rooted in the pain

I rise

I'm a black ocean ,leaping and wide,

Welling and swelling I bear in the tide.

(Still I Rise)

The poem is an example of African-American oppression. She shows how she determines to resist the fact of being a victim of oppression. She rejects the way her ancestors were portrayed in history. Instead, she will Rise, resist and fight. The poet likens herself to the sun and moon which rise in spite of everything. Angelou was born to live a poor life; however, she would act as if she is a rich person "oil wells" Rather than being defeated, she would laugh and rise,

Did you want see me broken?

Bowed head and lowered eyes?

Shoulders falling down like teardrops, 
Weakened by my soulful cries?

Although there is no more enslavement, still in deep in her soul, she suffers from Racism.

Out of the huts of history's shame

I rise

Up from a past that's rooted in pain

I rise

I'm a black ocean, leaping and wide,

Welling and swelling I bear in the tide.

Although blacks have suffered, black women in particular have experienced more suffering and oppression. This is shown clearly in Angelou's move form generalizing in the beginning of the poem talking about slavery in Americans history to speak about to the continued racism of women

Does my sexiness upset you?

Does it come as a surprise

That I dance like I've got diamonds

At the meeting of my thighs?

In this stanza, Angelou clarifies the whites' standards of beauty, however, she is so proud of herself and reflects upon this by stating that:

'Cause I walk like I've got oil wells

Pumping in my living room.

She affirms that she walks like someone who is very wealthy and rich. As most African American poets, Angelou refused to be marginalized; her poetry is a call for liberty and a trial to fight slavery. Angelou has experienced a lot of traumas but again and again she rises and resists. In her poem "And Still I Rise", Angelou says: 
Out of the huts of history is shame

I Rise

Up from a past that's rooted in pain

I Rise

I am a Black Ocean, leaping and wide,

Welling and swelling I bear in the tide

(Still I Rise)

Here, she is not only speaking about herself but also about her ancestors, the oppressed black women. She tries to shed light on the experience of black women and their suffering. In these lines, Angelou represents herself as a bird who wants to fly seeking freedom. Like a bird, she feels she is caged; however, she does not give up. She repeats that she will Rise in spite of the long journey of suffering and resistance. Angelou emphasizes the themes of prejudice, discrimination, and Racism that black women have experienced. She announces her refusal of slavery and inferiority.

In her poem" the calling of names" Angelou reveals the general experience of Racism that African American females had lived. Racism is well revealed in this poem, it is a very good example of black oppression. It introduces the image of the abused African-American male. AfricanAmericans did not have an identity they have no names other than those different names ascribed to them by the white oppressors. (Taghreed Hamed43)

He went to being called a colored man

After answering to 'hey, nigger"

Now that's a big jump

Anyway you figger 
African-Americans lost their respect and dignity. They also lose their identity as shown in the poem "Still I rise" Angelou, in this poem speaks about injustice faced by blacks. This horrible experience does not bother her on contrary, she asserts" I'll rise" and she repeats it more than one time.

She encourages black women not to give up as she confidently asserts:" Just like moons and like

Suns with the certainty of tides

Just like hopes springing high

Still I rise(163)

Racism is a central theme and can be found in most of Angelou's poetry. She speaks about the white racists who burnt the homes and properties of the black people. In the poem "Riot 60s"

Lightening: a hundred watts

Detroit, Newark and New York

Screeching nerves, exploding minds

Lives tied to

A Policeman's whistle

Racists actually don't feel with their hearts or see with their eyes. They are always blind to the truth. They easily kill and murder the black people.

National guard nervous with his shiny gun

Goose the motor quicker

Here's my nigga picka

Shoot him in the belly

Shoot him while he run

Racist people are always cruel; they deal with black people as if their lives are worthless and cheap. 
"And Still I Rise" is one of the most inspiring poems in regard of Racism. Angelou recalls the past of her ancestors who suffered from slavery, enslavement and oppression. All the time, Angelou is criticizing the oppression Blacks faced in the past and she encourages the African Americans to accept their identities.

The poem "Faces" Is another example of Racism

In the poem, Angelou addresses the African American people "Breathe, Brother, and displace a moment's hate with organized love" In her poem: "Still I Rise" she intends to leave the past behind and look forward to the future.

Leaving behind nights of terror and fear

I Rise

Into a daybreak that's wondrously clear

I Rise

As Angelou's ancestors succeeded to scarify, resist, and survive. Now she is the dream that they could not achieve in the past. She says:

Bringing the gifts that my ancestors gave,

I am the draw and the hope of the slave

I Rise

I Rise

I Rise

The image of the black female is repeated in Angelou's poetry. She talks about the dehumanization of the black female by the white community. "Our Grand Mother" is a poem that talks about the black female. Black females were objectified and sexually abused, they were also deprived of their humanity. (Surra Sami 53) in the poem "Our Grand Mothers" Angelou shows how women were treated in African American society.

She heard the names, 
swirling ribbons in the wind of history:

nigger, nigger bitch, heifer,

mammy, property, creature, ape, baboon,

whore, hot tail, thing, it.

She said, But my description cannot

fit your tongue, for

A black woman was called "creature, ape, baboon, whore, hot tail and thing" In a trial to dehumanize her. Angelou did not accept this insult. The description of women here is built on hatred, discrimination, and racism.

The research proves that Angelou asserts and recommends that black women can only attain their independence through work and education instead of childbearing and housework. Her poetry shows her sense of racist oppression that African American have been subjected to. She is also aware of sexist oppression that she realizes through her own experience. As she was a victim of sexual abuse when she was a child. She also worked as a prostitute for two years. Angelou's poetry exposes and resists both sexism and racism. She believes that gender inequity will not be achieved unless we get rid first of racial inequality. The researcher concludes that women are able to behave like men, simply, because women, although considered as powerless social group, they can have the same values and strategies of men. 


\section{Works Cited}

Blain, Virginia, Patricia Clements, and Isobel Grundy. The Feminist Companion to Literature in English: Women Writers from the Middle Ages to the Present. New Haven: Yale UP, 1990. Print.

Bloom, Harold. Maya Angelou's I Know Why the Caged Bird Sings.

Philadelphia: Chelsea House, 1998. Print.

Burt, Sharon, and Lauren Curtright. "Maya Angelou." (1998).

Christian, Barbara. "Angelou" Contemporary Authors, 1987.

Clintonlibrary42. "Maya Angelou's Poem "On the Pulse of Morning"." YouTube. YouTube, 18 Dec. 2012. Web.

Cochrane, Kira. Women of the Revolution: Forty Years of Feminism. London, Great Britain: Guardian, 2012. Print.

Collins, Patricia Hill. "The social construction of black feminist thought." Signs: Journal of Women in Culture and Society 14.4 (1989): 745-773.

Drešerová, Jana. Canary Petunias in Bloom: Black Feminism in Poetry by Alice Walker and Rita Dove. Diss. Masarykova univerzita, Filozofická fakulta, 2007.

Eckert, Penelope, and Sally McConnell-Ginet. Language and gender. Cambridge University Press, 2013.

Ghani, Mamuna, and Bushra Naz. "Race, feminism and representation-an inquiry into Maya Angelou's poetry." International Research Journal of Arts \& Humanities 35 (2007): 95-106.

Gottlieb, Annie. "Angelou” Contemporary Authors, 1987

Grumbach, Doris. "Maya Angelou" Contemporary Literary Criticism, 1980.

Guha, Saikat. "SONG OF THE CAGED BIRD: MAYA ANGELOU'S RESISTANCE TO RACISM AND SEXISM IN HER POETRY."

Hembrough, Tara. "Writing as an act of self-embodiment: Hurston, Moody, and Angelou combat systemic racial and sexual oppression." Journal of African American Studies 20.2 (2016): 164-182. 
Hilton, Als. Songbird: Maya Angelou Takes Another Look at Herself : New Yorker, 2002.

Holbrook, Amber M. Male Gender Role Stress, Attitudes Toward Feminism, and Coping. ProQuest, 2009.

Hooks, Bell. Black Women: Shapping Feminist Theory : Cudd, Ann E \& Andreasen, 1984

https://www.enotes.com/homework-help/what-theme-poem-still-rise-688077

Humm, Maggie, Modern feminisms: Political, Literary, Cultural. New York:

Columbia University Press, 1992.

Humm, Maggie, The dictionary of feminist theory. Columbus: Ohio State University Press, 1990.

Jaquin, Eileen , Maya Angelou in African American Autobiographers: A Source Book, ed. Emmanuel S. Nelson .Greenwood Press, 2002.

Jordan, June. "Maya Angelou" Contemporary Literary Criticism, 1980.

KHALED, Nouria Malika. Recovery from Trauma in Maya Angelou's I Know Why the Caged Bird Sings. Diss.

Kirkpatrick, Kathryn. "The Life and Works of Maya Angelou." Unpublished paper. Retrieved on March 10 (2014)

Koyana, Siphokazi and Rosemary Gray. Growing Up with Maya Angelou and

Sindiwe Magona: A Comparison, 2002.

Koyana, Siphokazi Z. The Heart of a Woman: Black Women's Lives in the United States and South Africa as Portrayed in the Autobiographies of Maya Angelou and Sindiwe Magona. Diss. Temple University, 1998.

Krisna, Silvania, and Liliek Soelistyo. "BLACK POWER IN MAYA ANGELOU'S "STILL I RISE”,"PHENOMENAL WOMAN", AND "WEEKEND GLORY"." K@ ta Kita1.1 (2013)

McPherson, Dolly A. Order Out of Chaos: The Autobiographical Works of Maya Angelou :P. Lang, 1990.

Naderi, Leila, Azita Amelirad, and Shiva Amelirad. "Maya Angelou's quest for an identity as a female black voice."

Nash, Julie. "Gender Roles and Sexuality in Victorian Literature." (1996): 560-562. 
Hanaa Eid, Mohamed Enani, Shaymaa Sayed Abdel Aatty. (BIJHS) 2020, 2 (1):67 - 92

Nilsen, Alleen P. “Maya Angelou 4 April 1928-” (Contemporary Literary Criticism, 1980.

PALUPI, NGESTI RETNO. "THE SOUNDS OF AFRICAN-AMERICAN IN MAYA ANGELOU'S POEMS: ALONE, STILL I RISE, CAGED BIRD AND EQUALITY." Jurnal IImiah Mahasiswa FIB 7.4 (2014).

Permatasari, Indiani Eka. "AN ANALYSIS OF FEMINISM IN MAYA ANGELOU'S POEMS BY USING HISTORICAL AND BIOGRAPHICAL APPROACHES." JIBS (Jurnal IImiah Bahasa dan Sastra) 3.2 (2016): 152-172.

Phields, Miriam E. "Development and psychometric investigation of the Phenomenal Woman Inventory: An emic measure of African American women's gender identity." (2002): 6019-6019.

Phields, Miriam E. Development and Psychometric Investigation of the Phenomenal Woman

Pratt-Clarke, Menah A. E. Critical Race, Feminism, And Education. 1st ed., New York, Palgrave Macmillan, 2010.

Ria Resky Hardianti Ilham , muhammadiyah university of suracarta 2015 Rich, Addrien, "When We Dead Awaken", in Feminist Literary Theory: A Reader, ed. Mary Eagleton, Oxford, Blackwell Publishers, 1996.

Roşcan, Nina Maria. "The Struggle of the Black Intellectual with Race and Gender Representation.(WEB DuBois, Frantz Fanon, Aimè Cẻsaire, Audre Lorde and Maya Angelou)." (2019).

Saunders, James Robert. "Breaking Out of the Cage: The Autobiographical Writings of Maya Angelou" in Twayne Companion to Contemporary Literature in English, ed. R.H.W. Dillard and Amanda Cockrell : Thomson Gale, 2002.

Showalter, Elaine, ed. New feminist criticism: essays on women, literature, and theory. New York: Pantheon Books, 1985.

Showalter, Elaine. "Modern American Women Writers." Barnes \& Noble. N.p. Web.

Showalter, Elaine. "Toward a Feminist Poetics," Women"s Writing and Writing About Women. London: Croom Helm, 1979.

Showalter, Elaine. A literature of their own: British women novelists from Brontë to Lessing. Princeton, N.J.: Princeton University Press, 1977. 
Smith, Sidonie Ann. "Maya Angelou 4 April 1928-"Contemporary Literary Criticism, 1980.

Snodgrass, Mary Ellen. Encyclopaedia of Feminist Literature. 1st ed., New York, Facts On File, 2013.

Suhadi, Agung, Kiagus Baluqiah, and Yupika Mariansyah. "The Comparative Analysis of Feminism Thought In Poems of Maya Angelou and Audre Lordre." Ninth International Conference on Applied Linguistics (CONAPLIN 9). Atlantis Press, 2016

Tangum, Marion M. and Marjorie Smelstor. Hurston's and Angelou's Visual Art: The Distancing Vision and the Beckoning Gaze :Southern Literary Journal, 1998.

Thiong'O, Wa Ngugi . The language of African Literature. Postcolonial Studies Reader. Ashcroft, Bill et al. (eds.) London: Routledge, 1995

Thompkin, Jane. Me and My Shadow". Oxford Reader on Feminism. Kemp, Sandra and Squires, Judith (eds.). New York: Oxford UP, 1997.

Tinnie, Wallis. "Maya Angelou" in The History of Southern Women's Literature, ed. Carolyn

Toller, Paige W., Elizabeth A. Suter, and Todd C. Trautman. "Gender role identity and attitudes toward feminism." Sex Roles51.1-2 (2004): 85-90.

Toppman, Lawrence. "Maya Angelou: The Serene Spirit of a Survivor." In Conversations with Maya Angelou. Ed. Jeffrey M. Elliot. Jackson and London: University Press of Mississippi, 1989.

Willis, Ellen.. "Radical Feminism and Feminist Radicalism." 1984

Wollstonecraft, Mary. "A Vindication of the Rights of Woman." In Mary

Wollstonecraft:PoliticalWritings, ed. Janet Todd. Toronto: University of Toronto Press. 1993

Wongpinit, Jongkit. "An Analysis of the Empowerment of Women as Reflected in Selected Works by African American Feminist Writers." (2006).

"Judith Butler." Britannica Library, Encyclopædia Britannica, 17 Jul. 2015. 08107o2rc.1103.y.https.library.eb.co.uk.mplbci.ekb.eg/levels/adult/article/JudithButler/571095. Accessed 17 Oct. 2018. 
Hanaa Eid, Mohamed Enani, Shaymaa Sayed Abdel Aatty. (BIJHS) 2020, 2 (1):67 - 92 "Role." Britannica Library, Encyclopædia Britannica, 11 Aug. 2018.

08107o2rc.1103.y.https.library.eb.co.uk.mplbci.ekb.eg/levels/adult/article/role/837 80. Accessed 17 Oct. 2018. 